\title{
KEDUDUKAN JABATAN DAN AKTA PEJABAT PEMBUAT AKTA TANAH DALAM SENGKETA DI PERADILAN TATA USAHA NEGARA
}

\author{
Bambang Yunarko \\ Fakultas Hukum Universitas Wijaya Kusuma Surabaya \\ e-mail: bambangyunarko@yahoo.co.id
}

\begin{abstract}
ABSTRAK
Pejabat Pembuat Akta Tanah merupakan pejabat umum yang bertugas membantu Kepala Kantor Pertanahan dalam melaksanakan kegiatan tertentu dalam pendaftaran tanah. Pejabat Pembuat Akta Tanah berwenang membuat akta yang berkaitan dengan perbuatan hukum mengenai hak atas tanah dan hak milik atas bantuan rumah susun. Pejabat Pembuat Akta Tanah merupakan pejabat tata usaha negara, namun akta yang dibuatnya bukanlah merupakan keputusan tata usaha negara sehingga tidak menjadi obyek sengketa di Pengadilan Tata Usaha Negara.

Kata Kunci: jabatan, akta, sengketa.

ABSTRACT

A land deed officer is a general officer who has function to help the head officer of the land office in the level of municipality, in regard to the registration of the land. The land deed officer has an authority to produce a legal certificate which is related to a legal acts for rights of the land and flats. Also the officer of land deed is the officer of administrative, however the deed or a certificate of the land which is legalized by the land deed officer is not product of administrative. Therefore it cannot be disputed in Administrative Court.
\end{abstract}

Keywords: position, deed or certificate, dispute.

\section{PENDAHULUAN}

Pejabat Pembuat Akta Tanah ialah pejabat umum yang berwenang untuk membuatkan akta otentik, berkaitan dengan perbuatan hukum mengenai hak atas tanah atau hak milik atas satuan rumah susun, pembebanan hak tanggungan, pemberian suatu hak baru, yang diharuskan oleh peraturan perundangundangan agar dinyatakan di dalam akta otentik, yang demikian itu menjamin kepastian tanggalnya, menyimpan minuta aktanya dan memberikan salinan dan kutipannya, semua itu sepanjang pembuatan akta-akta itu tidak juga ditugaskan atau dikecualikan kepada pejabat umum lainnya.

Dilihat peranannya, Pejabat Pembuat Akta Tanah (yang selanjutnya akan disebut PPAT) sebagaimana disebutkan di dalam Peraturan Pemerintah Nomor 37 Tahun 1998 tentang Peraturan Jabatan Pejabat Pembuat Akta Tanah (yang selanjutnya disebut PP No. 37 Tahun 1998), maka kewenangannya adalah membuat, serta mengesahkan akta pemindahan hak atas tanah atau hak milik atas satuan rumah susun kemudian, setelah dibuatkan akta pemindahan hak tersebut dapat didaftarkan pada Kantor Pertanahan Kabupaten atau Kota.
Dari mekanisme tersebut di atas maka dapat dilihat bahwa perbuatan atau tindakan hukum berupa pendaftaran tanah yang berasal dari pemindahan hak yang berupa jual beli harus didahului dengan pembuatan akta jual beli tanah dan disahkan oleh seorang pejabat yang disebut PPAT. Melihat peran dari PPAT dalam melaksanakan tugasnya tersebut berdasarkan pada PP No. 37 Tahun 1998, dalam hal ini PPAT merupakan pejabat umum yang membantu Kepala Kantor Pertanahan Kabupaten/Kota yang berkaitan dengan sah atau tidaknya akta pemindahan hak atas tanah atau dengan kata lain PPAT dapat dikatakan sebagai pejabat yang melaksanakan urusan tugas pemerintahan yang berupa rangkaian proses pendaftaran hak atas tanah, karena tanpa adanya akta dari PPAT maka tanah yang bersangkutan itu tidak dapat didaftarkan pada Kantor Pertanahan Kabupaten atau Kota. Dari uraian tersebut di atas dalam tulisan ini dapatlah diangkat permasalahan, apakah PPAT merupakan Pejabat Tata Usaha Negara, dan akta PPAT dapat dijadikan obyek sengketa di Peradilan Tata Usaha Negara. 


\section{PEMBAHASAN}

\section{Keputusan Tata Usaha Negara}

Keputusan yang merupakan salah satu instrumen yuridis bagi pemerintahan untuk dapat melakukan suatu tindakan dan keputusan pemerintah secara teoritis yang telah dikenal dengan istilah Beschikking yang dapat diberikan batasan antara lain, beschikking merupakan perbuatan hukum publik yang bersegi satu yang dilakukan oleh alat-alat pemerintah berdasarkan atas kewenangan dengan maksud terjadi perubahan hukum, dan tindakan hukum sepihak dalam lapangan pemerintah dan dilakukan oleh alat-alat pemerintah berdasarkan wewenang yang ada pada organ itu, dan perbuatan hukum publik yang bersegi satu yang dilakukan alat-alat pemerintah berdasarkan kekuasaan istimewa (S.F. Marbun dan Mahfud MD, 2009:75). Berangkat dari ketiga pengertian tentang batasan beschikking tersebut dapat diartikan beschikking merupakan perbuatan hukum publik yang bersegi satu atau perbuatan sepihak dari pemerintah dan bukan merupakan hasil persetujuan dua belah pihak, dan bersifat hukum publik diperoleh dari wewenang atau kekuasaan atau kekuasaan istimewa, dengan maksud terjadi perubahan dalam lapangan hubungan hukum.

Karakteristik beschikking antara lain, bersifat hukum publik, seperti juga halnya setiap keputusan administrasi lainnya, beschikking selalu dikeluarkan berdasarkan wewenang yang diberikan oleh suatu ketentuan hukum administrasi negara, dan bersifat sepihak, seperti suatu keputusan administrasi lainnya beschikking ternyata juga bersifat sepihak, sekalipun dikarenakan adanya permohonan, bersifat individual, konkret dan final, artinya individual adalah untuk orang tertentu, konkret artinya tidak abstrak dan final artinya sudah definitif sifatnya dan tidak memerlukan lagi persetujuan atasan atau instansi lain.

Peradilan Tata Usaha Negara merupakan peradilan yang berwenang menyelesaikan sengketa administrasi antar Badan atau Pejabat Tata Usaha Negara dengan individu atau badan hukum perdata sehingga peradilan tata usaha negara berfungsi sebagai sarana kontrol masyarakat terhadap tindakan pemerintah, sejalan dengan konsep negara hukum dimana kedudukan antara masyarakat dengan pemerintah adalah sejajar, karena itu di Indonesia sebagai negara hukum harus ada peradilan tata usaha negara maka didirikanlah Peradilan Tata Usaha Negara oleh pemerintah yang diatur dengan Undang-Undang Nomor 5 Tahun 1986 tentang Peradilan Tata Usaha Negara yang sampai sekarang telah mengalami 2 (dua) kali perubahan yaitu, pertama diubah dengan Undang-Undang Nomor
9 Tahun 2004 tentang Perubahan atas Undang-Undang Nomor 5 Tahun 1986 tentang Peradilan Tata Usaha Negara, selanjutnya dilakukan perubahan yang kedua yaitu diubah dengan Undang-Undang Nomor 51 Tahun 2009 tentang Perubahan Kedua atas UndangUndang Nomor 5 Tahun 1986 tentang Peradilan Tata Usaha Negara (yang selanjutnya disebut UU No. 5 Tahun 1986).

Di Peradilan Tata Usaha Negara yang menjadi obyek sengketa adalah keputusan/penetapan tertulis atau yang disamakan dengan itu, yang dikeluarkan atau ditolak, yaitu dikeluarkan oleh Pejabat atau Badan Tata Usaha Negara seperti yang tercantum dalam Pasal 1 angka 9 UU No. 5 Tahun 1986 bahwa keputusan atau penetapan tata usaha negara yang dapat disengketakan di Peradilan Tata Usaha Negara harus memenuhi syarat-syarat sebagai berikut:

Pertama, Keputusan Tertulis. Keputusan atau penetapan yang dikeluarkan oleh Pejabat atau Badan Tata Usaha Negara haruslah dalam bentuk tertulis. Hal ini adalah untuk memudahkan dari segi pembuktian. Bentuk tertulis itu dapat juga berupa nota dinas atau memo dan keputusan itu haruslah bersifat (Philipus Hadjon, 2005:136): 1. Konkret. Obyek yang akan diputuskan dalam surat keputusan tata usaha negara itu tidak bersifat abstrak tetapi berwujud tertentu atau dapat ditentukan, misalnya: Pemberhentian A sebagai pegawai negeri di Pemerintah Propinsi Jawa Timur, Penerbitan sertifikat tanah oleh Badan Pertanahan Nasional atas nama B; 2. Individual. ialah Keputusan Pejabat Tata Usaha Negara itu tidak ditujukan kepada umum, tetapi untuk orang tertentu, baik nama atau alamat yang dituju, apabila yang dituju oleh keputusan Tata Usaha Negara itu lebih baik dari seorang, maka nama tiap-tiap orang itu disebutkan dalam keputusan Tata Usaha Negara tersebut, misalnya: Nama-nama orang yang tanahnya terkena pelebaran jalan harus disebut satu per satu dalam lampiran surat keputusan; 3. Final. Keputusan Tata Usaha Negara itu sudah dapat dilaksanakan dan tidak perlu meminta persetujuan atasan ataupun instansi lain, keputusan yang masih memerlukan persetujuan atasan/instansi lain belum bersifat final, karena belum dapat menimbulkan hak dan kewajiban pada pihak bersangkutan misalnya, pemberhentian A seorang Dosen Kopertis sebagai tenaga pengajar oleh Rektor PTS (Keputusan Rektor bagi Dosen Kopertis) yang bersangkutan itu belum final, karena masih memerlukan persetujuan dari Kementerian Pendidikan dan Kebudayaan.

Kedua, Keputusan yang bersifat negatif. yaitu Pejabat atau badan tata usaha tidak mengeluarkan keputusan yang dimohonkan, sedangkan hal itu 
menjadi kewenangannya untuk dapat mengeluarkan keputusan, perbuatan tersebut sama dengan telah menolak mengeluarkan keputusan yang dimaksud (Pasal 3 ayat (2) UU No. 5 Tahun 1986). Apabila peraturan perundang-undangan yang bersangkutan tidak mengatur jangka waktu, maka setelah lewat jangka waktu 3 (tiga) bulan yaitu sejak diterimanya permohonan tersebut itu, maka pejabat atau Badan Tata Usaha Negara yang bersangkutan dianggap telah mengeluarkan keputusan penolakan.

Ketiga, Dibuat oleh Pejabat atau Badan Tata Usaha Negara secara sepihak. Keputusan yang dapat menjadi obyek sengketa dalam Peradilan Tata Usaha Negara, haruslah dikeluarkan oleh pejabat atau Badan Tata Usaha Negara secara sepihak walaupun sebelumnya ada permohonan.

Keempat, Menimbulkan akibat hukum. Akibat hukum telah timbul, apabila dengan dikeluarkannya keputusan atau penetapan itu menimbulkan kerugian bagi seseorang atau badan Hukum Perdata.

Seluruh elemen persyaratan dalam Pasal 1 butir ke-9 UU No. 5 Tahun 1986 harus terpenuhi secara kumulatif, barulah keputusan atau penetapan Pejabat Tata Usaha Negara tersebut menjadi kewenangan mengadili dari hakim Tata Usaha Negara.

\section{Pejabat Pembuat Akta Tanah (PPAT)}

Untuk menjamin kepastian hukum hak atas tanah, Pasal 19 ayat (1) Undang-Undang Nomor 5 Tahun 1960 tentang Peraturan Dasar Pokok-Pokok Agraria (yang selanjutnya disebut UUPA) menyatakan untuk dapat menjamin kepastian hukum oleh pemerintah diadakan pendaftaran atas tanah di seluruh wilayah Negara Republik Indonesia menurut ketentuan yang diatur dengan Peraturan Pemerintah.

Dari Pasal 19 ayat (1) tersebut, dalam rangka pelaksanaan pendaftaran tanah dibuatlah Peraturan Pemerintah Nomor 24 Tahun 1997 tentang Pendaftaran Tanah. Selanjutnya di dalam Pasal 7 Peraturan Pemerintah Nomor 24 Tahun 1997 memerintahkan bahwa pendaftaran tanah perlu mengatur jabatan pembuat akta tanah dengan Peraturan Pemerintah yang pada akhirnya dibuatlah PP No. 37 Tahun 1998 tentang Jabatan Pejabat Pembuat Akta Tanah (PPAT) sebagaimana perintah Pasal 7 Peraturan Pemerintah Nomor 24 Tahun 1997 tersebut.

Dalam PP No. 37 Tahun 1998 dalam Pasal 1 ada 3 (tiga) macam PPAT yaitu:

Pertama, PPAT ialah sebagai pejabat umum yang kewenangan untuk membuat akta otentik mengenai perbuatan hukum mengenai hak atas tanah atau hak milik atas satuan rumah susun di daerah kerjanya.
Syarat-syarat untuk dapat menjadi PPAT sebagai pejabat umum sebagaimana diatur dalam Pasal 6 PP No. 37 Tahun 1998 adalah Berkewarganegaraan Indonesia; Berusia sekurang-kurangnya 30 (tiga puluh) tahun; Berkelakuan baik yang dinyatakan dengan surat keterangan yang dibuat oleh kepolisian setempat; Belum pernah dihukum penjara, karena telah melakukan suatu kejahatan berdasarkan putusan pengadilan yang telah memperoleh keputusan tetap; Sehat jasmani dan rohani; Lulus program pendidikan spesialis notariat/program pendidikan khusus PPAT yang diselenggarakan oleh lembaga pendidikan tinggi; Lulus ujian yang diselenggarakan oleh kantor Menteri Negara Agraria atau Badan Pertanahan Nasional.

Setelah memenuhi persyaratan tersebut di atas seseorang baru dapat diangkat PPAT sebagai pejabat umum, pengangkatan PPAT sebagai pejabat umum dilakukan oleh Kepala Badan Pertanahan Nasional Republik Indonesia (yang selanjutnya disebut BPN) untuk suatu daerah kerja tertentu yang meliputi satu wilayah kerja Kantor Pertanahan Kabupaten/Kota. Sebelum menjalankan jabatannya PPAT diwajibkan bersumpah dihadapan Kepala Kantor Pertanahan Kabupaten atau Kota di daerah kerja PPAT yang bersangkutan. Dalam waktu 1 (satu) bulan setelah pengambilan keputusan sumpah jabatan PPAT wajib menyampaikan alamat kantor, contoh paraf dan tera cap/stempel jabatan kepada Kepala Kantor Wilayah BPN Propinsi, Bupati, Walikota, Ketua Pengadilan Negeri dan Kepala Kantor Pertanahan yang meliputi wilayah kerja PPAT yang bersangkutan. PPAT yang belum menyampaikan sumpah jabatan, maka akta yang dibuat tidak sah dan tidak dapat dijadikan dasar bagi perubahan data pendaftaran tanah.

Sebagai seorang pejabat umum PPAT dilarang meninggalkan kantornya lebih dari 6 (enam) hari kerja berturut-turut kecuali dalam rangka menjalankan cuti, dan Permohonan cuti diajukan secara tertulis kepada: Kepala Kantor Pertanahan Kabupaten/Kota setempat untuk cuti kurang 3 (tiga) bulan; Kepala Kantor Wilayah BPN Propinsi untuk cuti lebih dari 3 (tiga) bulan tetapi kurang dari 6 (enam) bulan; Menteri Negara Agraria/Kepala BPN untuk cuti lebih dari 6 (enam) bulan.

Selain menjalankan cuti untuk sementara tugastugas dan kewenangan PPAT dapat dilaksanakan oleh PPAT pengganti atas permohonan PPAT yang bersangkutan, persyaratan PPAT pengganti adalah telah lulus program pendidikan strata satu jurusan hukum dan telah menjadi pegawai di kantor PPAT dan yang bersangkutan telah sekurang-kurangnya selama 2 (dua) tahun, sebelum menjalankan tugas 
dari kewenangannya PPAT pengganti harus diambil sumpah oleh Kepala Kantor Pertanahan Daerah kerja PPAT yang bersangkutan.

Selain dilarang meninggalkan kantornya lebih dari 6 (enam) hari kerja berturut-turut kecuali cuti seperti tersebut di atas PPAT sebagai pejabat umum dilarang merangkap menjadi Advokat dan Pegawai Negeri atau Pegawai Badan Usaha Milik Negara/Daerah, tetapi diperbolehkan merangkap jabatan sebagai Notaris atau Konsultan Hukum.

Masa kerja jabatan PPAT sebagai pejabat umum berakhir apabila: Meninggal dunia; Telah mencapai usia 65 (enam puluh lima) tahun; Mengundurkan diri; Tidak mampu menjalankan tugas karena kesehatan badan dan jiwa terganggu; Dijatuhi hukuman pidana 5 (lima) tahun yang sudah berkekuatan hukum tetap; Melakukan pelanggaran berat terhadap larangan dan kewajiban PPAT; Diberhentikan oleh Menteri.

Kedua, PPAT Sementara, adalah disebut pejabat pemerintah karena jabatannya untuk melaksanakan tugas PPAT dengan membuat akta PPAT di daerah yang belum cukup terdapat PPAT.

Untuk melayani masyarakat dalam pembuatan akta PPAT di daerah yang belum cukup terdapat PPAT atau untuk melayani golongan masyarakat tertentu dalam pembuatan Akta PPAT tertentu pula, Kepala BPN dapat menunjuk Camat atau Kepala Desa untuk sebagai PPAT Sementara di daerah kerjanya.

Sebelum memulai menjalankan jabatannya PPAT Sementara wajib mengangkat sumpah jabatan PPAT dihadapan Kepala Kantor Pertanahan Kabupaten atau Kota di daerah kerja PPAT yang bersangkutan, apabila sumpah jabatan dan PPAT Sementara belum juga dilaksanakan, maka akta yang dibuat tidak sah dan tidak dapat dijadikan dasar bagi perubahan data pendaftaran tanah.

Pengambilan sumpah jabatan PPAT Sementara bagi Kepala Desa tersebut dilakukan oleh Kepala Kantor Pertanahan di Kantor Kepala Desa yang bersangkutan. Dalam waktu 1 (satu) bulan setelah pengambilan sumpah jabatan PPAT Sementara wajib menyampaikan alamat kantornya, dan contoh tanda tangan, contoh paraf, dan tera cap/stempel jabatannya kepada Kepala Kantor Wilayah BPN Propinsi, Bupati, Walikota, Ketua Pengadilan Negeri dan Kepala Kantor Pertanahan yang meliputi wilayah kerja PPAT yang bersangkutan.

Bagi PPAT Sementara tidak ada larangan untuk meninggalkan kantornya lebih dari 6 (enam) hari kerja berturut-turut dan tidak mempunyai hak cuti. Sebagaimana berlaku pada PPAT sebagai pejabat umum, dan demikian juga berkaitan dengan masa berhenti kerja dari PPAT Sementara adalah apabila PPAT Sementara yang bersangkutan sudah tidak lagi memegang jabatan Camat, Kepala Desa atau diberhentikan oleh Menteri.

Ketiga, PPAT Khusus, adalah pejabat BPN yang telah ditunjuk karena jabatannya, untuk melaksanakan tugas-tugas dari PPAT dengan membuat akta PPAT tertentu, khusus dalam rangka pelaksanaan program atau tugas pemerintah tak tertentu. Kepala Kantor Pertanahan sebagai PPAT dapat melayani pembuatan akta PPAT yang diperlukan dan dalam hal programprogram pelayanan masyarakat atau untuk melayani pembuatan akta PPAT tertentu bagi negara sahabat berdasarkan asas resiprositas sesuai pertimbangan dari Kementerian Luar Negeri.

Di dalam menjalankan tugas-tugas jabatan PPAT Khusus tidak perlu melakukan sumpah jabatan PPAT dihadapan Kepala Kantor Pertanahan Kabupaten/Kota sebagaimana berlaku pada PPAT sebagai pejabat umum dan PPAT Sementara, sama halnya dengan PPAT Sementara PPAT Khusus juga tidak ada larangan untuk meninggalkan kantornya lebih dari 6 (enam) hari kerja berturut-turut dan tidak mempunyai hak cuti, masa berhenti untuk tidak melaksanakan tugas PPAT Khusus apabila yang bersangkutan sudah tidak memegang jabatan sebagai kepala kantor pertanahan atau diberhentikan oleh Menteri. PPAT Khusus hanya berwenang membuat akta mengenai perbuatan hukum yang secara khusus disebut dalam penunjukannya, hal ini biasanya terkait dengan program atau tugas pemerintah, misalnya yang terkait dengan programprogram pemerintah terkait dengan pembuatan atau pelebaran jalan raya yang berkaitan dengan tanah masyarakat.

\section{Pejabat Tata Usaha Negara}

Dalam UU No. 5 Tahun 1986 dijumpai adanya sebutan-sebutan hukum, misalnya Badan atau Pejabat Tata Usaha Negara, Keputusan Tata Usaha Negara, Sengketa Tata Usaha Negara, dan sebagainya.

Di dalam UU No. 5 Tahun 1986 Pasal 1 angka 8 yang dimaksud Badan atau Pejabat Tata Usaha Negara yaitu badan atau pejabat yang melaksanakan urusan pemerintahan berdasarkan suatu peraturan perundang-undangan yang telah berlaku. Penjelasan Pasal 1 angka 8, bahwa urusan pemerintahan ialah kegiatan yang bersifat eksekutif dan yang dimaksud dengan pemerintah adalah keseluruhan kegiatan yang menjadi tugas dan dilaksanakannya oleh para Badan dan Jabatan/Pejabat Tata Usaha Negara yang bukan pembuatan peraturan dan mengadili. Akan tetapi dalam praktik tidaklah gampang untuk menentukan 
secara limitatif Pejabat atau Badan Tata Usaha Negara sebagai tergugat dalam sengketa tata usaha negara, karena di dalam praktiknya ada tugas-tugas eksekutif yang dilimpahkan pelaksanaanya kepada lembaga legislatif maupun yudikatif, malahan ada kalanya dilimpahkan kepada pihak lembaga swasta, hal ini terjadi karena sistem ketatanegaraan tidak mengenal pemisahan kekuasaan atau Separation of Power sebagaimana diajarkan oleh Montesquieu melainkan pendistribusian kekuasaan atau Distribution of Power (Darwan Prinst, 1993:27).

Dalam Rancangan UU No. 5 Tahun 1986 tentang Peradilan Tata Usaha Negara dipergunakan formulasi sebagai berikut, Badan Tata Usaha Negara adalah badan yang menyelenggarakan kegiatan tata usaha negara.

Dalam rapat panitia khusus di Dewan Perwakilan Rakyat terjadi pembicaraan di antara berbagai fraksi dan pemerintah, oleh pemerintah dijelaskan dengan mengambil alih pendapat Indroharto, sebagaimana yang dimuat didalam buku beliau berjudul Usaha Memahami Undang-Undang tentang Peradilan Tata Usaha Negara, dalam bukunya beliau mengatakan bahwa mengenai apa dan siapa yang dimaksud dengan Badan atau Jabatan Tata Usaha Negara itu menurut Pasal 1 ayat (2) UU No. 5 Tahun 1986, ukurannya ditentukan fungsi yang di laksanakan oleh Badan atau Jabatan Tata Usaha Negara pada saat tindakan hukum itu dilakukan. Apabila suatu tindakan hukum yang dilakukan pada saat itu berdasarkan peraturan perundang-undangan yang berlaku merupakan suatu pelaksanaan dari urusan pemerintahan, maka apa dan siapa saja yang melaksanakan fungsi itu, pada saat itu dapat dianggap sebagai suatu Badan atau Jabatan Tata Usaha Negara, dengan demikian ukuran yang digunakan oleh beliau bersifat fungsional (Indroharto, 1996:64).

Dari pendapat Indroharto, penulis sependapat juga tentang pengertian Badan Tata Usaha Negara, bukanlah seperti yang disebutkan sehari-hari secara formal yaitu Presiden, Menteri, Bupati, Walikota atau Kepala Dinas, akan tetapi lebih ditentukan oleh fungsi yang dilaksanakan oleh Badan atau Jabatan Tata Usaha Negara pada saat tindakan hukum Tata Usaha Negara itu dilakukan, hal ini didasari pada kenyataan saat ini masih banyak tugas-tugas yang seharusnya dilakukan oleh pemerintah, utamanya di bidang eksekutif yang dilimpahkan kepada lembagalembaga swasta, misalnya di bidang pendidikan dari Sekolah Dasar sampai Perguruan Tinggi di bidang kesehatan, dengan diberikannya izin kepada lembagalembaga swasta untuk mengelola rumah sakit swasta, dimana pada bidang pendidikan, kesehatan itu adalah merupakan tanggung jawab pemerintah juga. Penulis dapat memahami hal ini terjadi karena sampai saat ini pemerintah belum mampu untuk bisa mengelola kedua kebutuhan masyarakat, sehingga diperlukan partisipasi swasta untuk membantu tugas-tugas yang seharusnya menjadi tanggung jawab pemerintah.

Lembaga-lembaga swasta dapat dikategorikan sebagai Badan atau Jabatan Tata Usaha Negara oleh para hakim Peradilan Tata Usaha Negara. Sebagai contohnya, Peradilan Tata Usaha Negara Semarang telah menerima gugatan dari Arief Budiman, Dosen Universitas Satya Wacana Salatiga, yang menggugat Rektor Universitas Satya Wacana yang memecat Arief Budiman sebagai Dosen Tetap di Perguruan Tinggi tersebut. Dengan diterimanya gugatan Arief Budiman terhadap Surat Keputusan Rektor Universitas Satya Wacana Salatiga (yang merupakan lembaga Perguruan Tinggi Swasta) oleh Peradilan Tata Usaha Negara Semarang, hal ini membuktikan Surat Keputusan Rektor Pergururan Tinggi Swasta dapat menjadi obyek sengketa di Peradilan Tata Usaha Negara sehingga pengertian Badan atau Jabatan Tata Usaha Negara itu tidak saja diartikan dalam pengertian formal tetapi juga fungsional.

Tetapi sebaliknya ada yang berpendapat memakai ukuran yang bersifat formal struktural, yaitu hanya terbatas pada mereka yang berdasarkan pada struktur organisatoris dan secara formal berada dalam jajaran eksekutif misalnya, Presiden, Menteri, Gubernur, Bupati, Walikota, Kepala Dinas dan lain lain, karena menurut pendapat ini yang dimaksud dengan Badan atau Jabatan Tata Usaha Negara hanyalah dilihat secara sempit struktural dan terbatas pokok pegawaipegawai negeri atau pejabat negara yang berada dalam jajaran eksekutif atau pemerintahan saja.

Pengertian seperti ini sebagaimana dikemukakan oleh Philipus M. Hadjon, bahwa suatu pemerintah dapat dilihat dari 2 (dua) sudut yaitu, Pemerintah dalam arti fungsi yakni kegiatan yang mencakup aktifitas pemerintah, serta Pemerintah dalam arti organisasi yaitu kumpulan dari kesatuan-kesatuan pemerintahan.

Badan atau Pejabat Tata Usaha Negara merupakan unsur-unsur pokok dan terbesar dari pemerintahan diantara sekian banyaknya penyelenggara urusan pemerintahan, merekalah yang disebut Badan/Pejabat Tata Usaha Negara terutama yang berada dan berasal dari lingkungan eksekutif baik di pemerintahan pusat atau pun di pemerintahan daerah, yaitu dari Presiden sebagai suatu perangkat yang merupakan organisasi pemerintahan tertinggi (Habib Adjie, 2011:36). 


\section{Kedudukan Jabatan dan Akta PPAT}

Sebelum kita mengajukan gugatan di Peradilan Tata Usaha Negara alat bukti harus dipersiapkan sebelumnya, hal ini demi kelancaran penanganan perkara dan keberhasilan suatu gugatan yang akan diajukan. Demikian juga bagi tergugat alat buktialat bukti perlu dipersiapkan untuk menggagalkan gugatan penggugat, perlu diingat tidak semua alat bukti harus ditampilkan di pengadilan, akan tetapi cukup alat bukti yang menguntungkan bagi para pihak saja yang ditampilkan di persidangan, salah satu alat bukti yang sering ditampilkan oleh para pihak di depan persidangan adalah alat bukti surat atau tulisan yang berupa akta otentik. Akta otentik yaitu surat yang dibuat oleh atau dihadapan seorang pejabat umum yang menurut peraturan perundang-undangan berwenang membuat surat itu dengan maksud untuk dipergunakan sebagai alat bukti tentang peristiwa atau peristiwa hukum yang tercantum didalamnya. Pejabat Umum yang dimaksud Notaris, PPAT, Camat, Hakim dan lain-lainnya sesuai dengan wilayah hukum dan fungsi tugas masing-masing. Bukti surat otentik, merupakan alat bukti yang kuat, isinya dianggap benar sampai terbukti sebaliknya, oleh karena itu akta otentik merupakan alat bukti yang sempurna.

PPAT sebagai pejabat umum, PPAT berdasarkan Pada Pasal 1 angka 1 PP No. 37 Tahun 1998 diberi kekosongan untuk membuatkan akta-akta otentik mengenai perbuatan hukum tertentu mengenai hak atas tanah atau hak milik atas satuan rumah susun.

Dalam keadaan seperti di atas, maka akta dan jabatan PPAT berpotensi dan dapat dijadikan pihak tergugat serta obyek gugatan oleh para pihak yang berkepentingan di peradilan, baik itu di Peradilan Umum, Peradilan Agama, Peradilan Militer atau pun di Peradilan Tata Usaha Negara. Dalam Pasal 1 angka 10 UU No. 5 Tahun 1986 menyebutkan bahwa yang dimaksud dengan Sengketa Tata Usaha Negara adalah sengketa yang timbul dalam bidang Tata Usaha Negara antara orang atau badan hukum perdata atau Pejabat Tata Usaha Negara, baik di pusat maupun di daerah akibat dikeluarkannya suatu keputusan Tata Usaha Negara termasuk sengketa kepegawaian berdasarkan perundang-undangan yang berlaku.

Dilihat dari diberikan kewenangan PPAT seperti yang disebutkan pada Pasal 1 angka 1 PP No. 37 Tahun 1998, maka PPAT diberikan kewenangan untuk membuat dan mengesahkan akta peradilan hak atas tanah atau Hak Milik atas Satuan Rumah Susun, yang kemudian setelah dibuatkan akta jual belinya dapat didaftarkan pada Kantor Pertanahan Kabupaten/Kota. Dari mekanisme rangkaian perbuatan atau tindakan hukum berupa pendaftaran tanah yang berasal dari jual beli, harus didahului oleh pembuatan akta jual beli tanah dan pengesahannya oleh PPAT, tanpa itu tanah yang bersangkutan tidak dapat didaftarkan pada Kantor Pertanahan Kabupaten/Kota.

Dalam fungsi yang demikian itu dan pada saat itu maka kapasitas PPAT dapat dikategorikan sebagai Pejabat Tata Usaha Negara, menjalankan kegiatan urusan pemerintahan yang berupa rangkaian proses pendaftaran tanah dan berdasarkan Undang-Undang Nomor 5 Tahun 1960 tentang Pokok-Pokok Agraria dan Peraturan Pemerintah Nomor 24 Tahun 1997 tentang Pendaftaran Tanah, semua itu merupakan kegiatan urusan pemerintahan. Namun demikian hal tersebut tidak berarti secara langsung PPAT dan akta PPAT dapat atau bisa secara langsung digugat atau digunakan sebagai obyek sengketa di Peradilan Tata Usaha Negara (Philipus M. Hadjon, 1994:18).

Menurut penulis, Akta PPAT bukan suatu akta yang dilahirkan berdasarkan perbuatan hukum publik akan tetapi di lahirkan berdasarkan hukum perdata yaitu jual-beli sehingga akta PPAT tidak dapat digolongkan sebagai suatu beschikking yang bersifat sepihak dan bersifat hukum publik sehingga akta PPAT bukan merupakan suatu beschikking, karenanya akta PPAT tidak dapat dijadikan obyek Sengketa di Peradilan Tata Usaha Negara sekalipun PPAT berfungsi pada saat itu sebagai Pejabat Tata Usaha Negara. Andaikan dikatakan bahwa perbuatan mengesahkan jual-beli tanah tersebut merupakan produk hukum yang telah dituangkan dalam bentuk beschikking, akan tetapi beschikking yang demikian tetap sebagai perbuatan hukum perdata yaitu jual beli (bersegi dua) yang tidak bersifat sepihak dimana PPAT tidak bisa memaksakan pihak pembeli dan pihak penjual dalam keputusannya, maka disinilah letak karakter hukum perdatanya akta jual beli yang dibuat oleh PPAT, hal ini secara tegas disebutkan di dalam Pasal 2 huruf a UU No. 5 Tahun 1986.

Meskipun demikian bukan berarti PPAT dan akta PPAT tidak bisa digugat di lembaga Peradilan, maka pihak-pihak yang merasa dirugikan dapat melakukan gugatan ke Peradilan Umum melalui gugatan perdata dengan menggunakan Pasal 1365 Kitab UndangUndang Hukum Perdata yaitu perbuatan melawan hukum.

\section{PENUTUP \\ Kesimpulan}

Jabatan PPAT dapat diajukan sebagai tergugat ke Peradilan Tata Usaha Negara karena PPAT termasuk dikategorikan sebagai Pejabat Tata Usaha Negara 
sebagaimana dimaksud yang dalam Pasal 1 angka 8 UU No. 5 Tahun 1986 tentang Peradilan Tata Usaha Negara, dan Akta PPAT tidak dapat dijadikan obyek sengketa di Peradilan Tata Usaha Negara, karena Akta PPAT bukan termasuk Keputusan Tata Usaha Negara atau Beschikking sebagaimana yang dimaksud dalam Pasal 1 angka 9 dan Pasal 2 huruf a UU No. 5 Tahun 1986 tentang Peradilan Tata Usaha Negara.

\section{Rekomendasi}

Tanah dapat diwariskan secara turun-temurun dan bertambah tahun mempunyai nilai ekonomi yang sangat tinggi, oleh karena itu permasalahan tanah menjadi sangat penting dan sensitif dalam kehidupan masyarakat. PPAT sebagai pejabat yang telah diberi kewenangan untuk memproses peralihan hak atas tanah, mempunyai kedudukan yang sangat strategis berkaitan dengan proses peralihan hak atas tanah. Maka PPAT harus teliti dan cermat serta profesional di dalam menjalankan tugas pokok dan fungsi, sekaligus PPAT tidak dianggap sebagai penyebab timbulnya persengketaan tanah di masyarakat.

\section{DAFTAR PUSTAKA}

Buku:

Adjie, Habib, 2011, Majelis Pengawas Notaris sebagai Pejabat Tata Usaha Negara, Bandung: Refika Aditama.

Hadjon, Philipus M., 1994, Fungsi PPAT menurut PP 10 Tahun 1961, Surabaya: Airlangga Press. , 2005, Pengantar Hukum Administrasi Indonesia (Introduction to The Indonesia
Administrative Law), Yogyakarta: Gadjah Mada University Press.

Indroharto, 1996, Usaha Memahami Undang-Undang Peradilan Tata Usaha Negara, Jakarta: Pusaka Sinar Harapan.

Lotulung, Paulus Efendi, 1986, Pengertian Pejabat Tata Usaha Negara dikaitkan dengan Fungsi PPAT menurut PP 10 Tahun 1961, Media Notariat.

Marbun, S.F. dan Mahfud MD, 2009, Pokok-pokok Hukum Administrasi Negara, Yogyakarta: Liberty.

Prinst, Darwan, 1993, Strategi Memenangkan Perkara Tata Usaha Negara, Bandung: Citra Aditya Bakti.

\section{Peraturan Perundang-undangan:}

Undang-Undang Nomor 5 Tahun 1960 tentang PokokPokok Agraria.

Undang-Undang Nomor 5 Tahun 1986 tentang Peradilan Tata Usaha Negara.

Undang-Undang Nomor 9 Tahun 1986 tentang Perubahan atas Undang-Undang Nomor 5 Tahun 1986 tentang Peradilan Tata Usaha Negara.

Undang-Undang Nomor 51 Tahun 2009 tentang Perubahan Kedua atas Undang-Undang Nomor 5 Tahun 1986 tentang Peradilan Tata Usaha Negara.

Peraturan Pemerintah Nomor 24 Tahun 1997 tentang Pendaftaran Tanah.

Peraturan Pemerintah Nomor 37 Tahun 1998 tentang Jabatan Pejabat Pembuat Akta Tanah. 